\title{
Decomposition of gas-phase toluene by the combination of ozone and photocatalytic oxidation process $\left(\mathrm{TiO}_{2} / \mathrm{UV}, \mathrm{TiO}_{2} / \mathrm{UV} / \mathrm{O}_{3}\right.$, and $\left.\mathrm{UV} / \mathrm{O}_{3}\right)$
}

\author{
Kuo-Pin Yu ${ }^{\text {a,b,1 }}$, Grace W.M. Lee ${ }^{\text {a,* }}$ \\ ${ }^{a}$ Graduate Institute of Environmental Engineering, National Taiwan University, 71 Chou-Shan Rd., Taipei 10673, Taiwan, ROC \\ ${ }^{\mathrm{b}}$ Institute of Chemistry, Academia Sinica, 128 Academia. Rd., Nankang District, Taipei 11529, Taiwan, ROC \\ Received 22 November 2005; received in revised form 20 March 2007; accepted 21 March 2007 \\ Available online 25 March 2007
}

\begin{abstract}
The gas-phase toluene removal efficiencies by photocatalytic oxidation $\left(\mathrm{TiO}_{2} / \mathrm{UV}\right)$, the combination of ozone and photocatalytic oxidation $\left(\mathrm{TiO}_{2} / \mathrm{UV} / \mathrm{O}_{3}\right)$, and the $\mathrm{UV} / \mathrm{O}_{3}$ reaction were tested using a quartz tube photoreactor. The experiments were conducted under various ozone concentrations (3.3-15 ppm), toluene concentrations (1-9 ppm), relative humidity (5-80\%), and gas flow rates (200-1200 mL/min). The toluene oxidation rates (TORs) of $\mathrm{TiO}_{2} / \mathrm{UV} / \mathrm{O}_{3}$, and $\mathrm{UV} / \mathrm{O}_{3}$ reactions were proportional to the ozone concentrations. $\mathrm{The} \mathrm{TORs}$ of $\mathrm{TiO} / 2 / \mathrm{UV}, \mathrm{TiO} / 2 / \mathrm{UV} / \mathrm{O}_{3}$, and $\mathrm{UV} / \mathrm{O}_{3}$ reactions increased with toluene concentration. However, there were negative correlations between the toluene removal efficiencies of these three kinds of reactions and the toluene concentrations. The order of the TORs and the $\mathrm{CO}_{2}$ yield rates of these three reactions were TiO $/ \mathrm{UV} /$

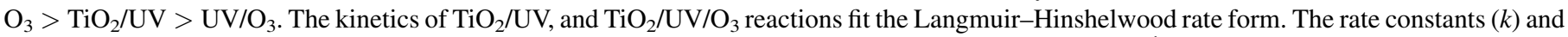
Langmuir adsorption constants $(K)$ are as follows: $\mathrm{TiO}_{2} / \mathrm{UV}: k=0.0102 \mathrm{ppm} \mathrm{m} / \mathrm{s}, K=0.146 \mathrm{ppm}^{-1} ; \mathrm{TiO}_{2} / \mathrm{UV}^{-\mathrm{O}_{3}}: k=0.0268 \mathrm{ppm} \mathrm{m} / \mathrm{s}$, $K=0.0796 \mathrm{ppm}^{-1}$. The reciprocal of $\mathrm{UV} / \mathrm{O}_{3}$ reaction rate showed a positive linear relationship with the reciprocals of humidity and of toluene concentration. Ozone, also an air pollutant, was removed in the $\mathrm{TiO}_{2} / \mathrm{UV} / \mathrm{O}_{3}$, and $\mathrm{UV} / \mathrm{O}_{3}$ reactions. The ozone removal efficiency of $\mathrm{TiO} / 2 / \mathrm{UV} / \mathrm{O}_{3}$ reaction in the presence and absence of toluene ranged from 61.1 to $99.5 \%$ and 38.1 to $95.1 \%$, respectively.
\end{abstract}

(C) 2007 Elsevier B.V. All rights reserved.

Keywords: Photocatalyst; Ozone; Toluene; Advance oxidation process; Langmuir-Hinshelwood kinetics

\section{Introduction}

Volatile organic compounds (VOCs) are common air pollutants and can be found in both outdoor and indoor settings. VOCs can react with $\mathrm{NO}_{x}$ to form tropospheric $\mathrm{O}_{3}$ which results in smog in urban air [1]. Exposure to VOCs might cause toxic effects to central nervous system and internal organs, and might cause symptoms, such as headache, respiratory tract irritation, dizziness and nausea, known as the sick building syndrome (SBS) [2,3].

For VOCs emission sources of high concentrations, catalytic treatments, such as catalytic incineration and catalytic combustion, have been well developed. However, these treatments require high temperatures $\left(200-900{ }^{\circ} \mathrm{C}\right)$ and high

\footnotetext{
* Corresponding author. Tel.: +886 23633249; fax: +8862 23633249.

E-mail addresses: f89541105@ntu.edu.tw (K.-P. Yu),

gracelee@ntu.edu.tw (G.W.M. Lee).

${ }^{1}$ Tel.: 886227898529.
}

concentrations (several hundred of ppm) of oxidizable compounds for successful operation, and are not cost-effective for low pollutant concentrations [4]. Among those available potential air-cleaning technologies for contamination of lower VOCs concentrations and indoor applications, photocatalytic oxidation (PCO) causes extensive concern recently. $\mathrm{PCO}$ can oxidize VOCs to carbon dioxide $\left(\mathrm{CO}_{2}\right)$ and water $\left(\mathrm{H}_{2} \mathrm{O}\right)$ under ambient temperature [5-7], and is capable of controlling microbial contaminations which are one of the sources of indoor VOCs.

Although PCO seems to be a promising technology for controlling VOCs contaminations of low concentrations, however, there are still some problems with this technology. For example, many irritative reaction intermediates, such as aldehydes and carboxylic acids, were found in PCO reactions $[12,13]$. Some of these intermediates may result in photocatalyst deactivation [8-11]. Illuminating the deactivated photocatalyst with ultraviolet (UV) light under high relative humidity in the absence of VOCs can regenerate the activity of 
photocatalyst $[14,15]$, but this method needs a spare unit for replacement during the regeneration. Wang et al. [16] found that ozone $\left(\mathrm{O}_{3}\right)$ added into the PCO reaction system had a positive effect on the regeneration of the photocatalyst. Jeong et al. [17] demonstrated that the VOCs removal efficiency and the $\mathrm{CO}_{2}$ selectivity of $\mathrm{PCO}$ when using a UV lamp of short wavelength $(185+254 \mathrm{~nm})$ was better than that when using a UV lamp of long wavelengths (254 and $365 \mathrm{~nm})$. Many reactive oxidants, including $\mathrm{O}_{3}, \mathrm{O}\left({ }^{1} \mathrm{D}\right)$, and $\mathrm{O}\left({ }^{3} \mathrm{P}\right)$, were formed when $\mathrm{O}_{2}$ was illuminated with a UV lamp of short wavelength. These added reactive oxidants can enhance the effectiveness of PCO.

In this study, we investigated the decomposition of gasphase toluene by the combination of ozone (a reactive oxidant) and PCO. There were three reactions $-\mathrm{TiO}_{2} / \mathrm{UV}, \mathrm{TiO}_{2} / \mathrm{UV} / \mathrm{O}_{3}$, and $\mathrm{UV} / \mathrm{O}_{3}$ reactions taking place in the experimental system. The experiments were conducted under different toluene concentrations (1-9 ppm), gas flow rates (200-1200 mL/min), relative humidity $(5-80 \%)$, and $\mathrm{O}_{3}$ concentrations (3.3$15 \mathrm{ppm}$ ) to investigate the effect of these factors on the toluene oxidation rates (TORs) and the $\mathrm{CO}_{2}$ yield rates.
Toluene was chosen as the target compound because it is one of the frequently encountered organic compounds in indoor environments [19]. Furthermore, toluene is listed as one of the surrogates for the six major classes of indoor VOCs (aromatic, aldehyde, alkane, ketone, alcohol, and chlorocarbon) by the American Society of Heating, Refrigerating, and Air-Conditioning Engineers (ASHRAE) [20]. The major use of toluene is as a mixture additive to improve the octane number of gasoline. Toluene is also used as a solvent in paints, coatings, adhesives, inks, and cleaning agents and is also used in the production of plastic polymers [18]. Exposure to toluene may cause the eye, nasal, mucous membrane, and respiratory tract irritation [21-23].

\section{Methodology}

\subsection{Oxidation reaction system}

The schematic diagram of the experimental system is shown in Fig. 1(a). A 45-cm-long and 2.5-cm-interior-diameter quartz tube was used as the photoreactor. We set a $107.5-\mathrm{cm}^{2}$-glass plate coated with Degussa P25 titania photocatalyst
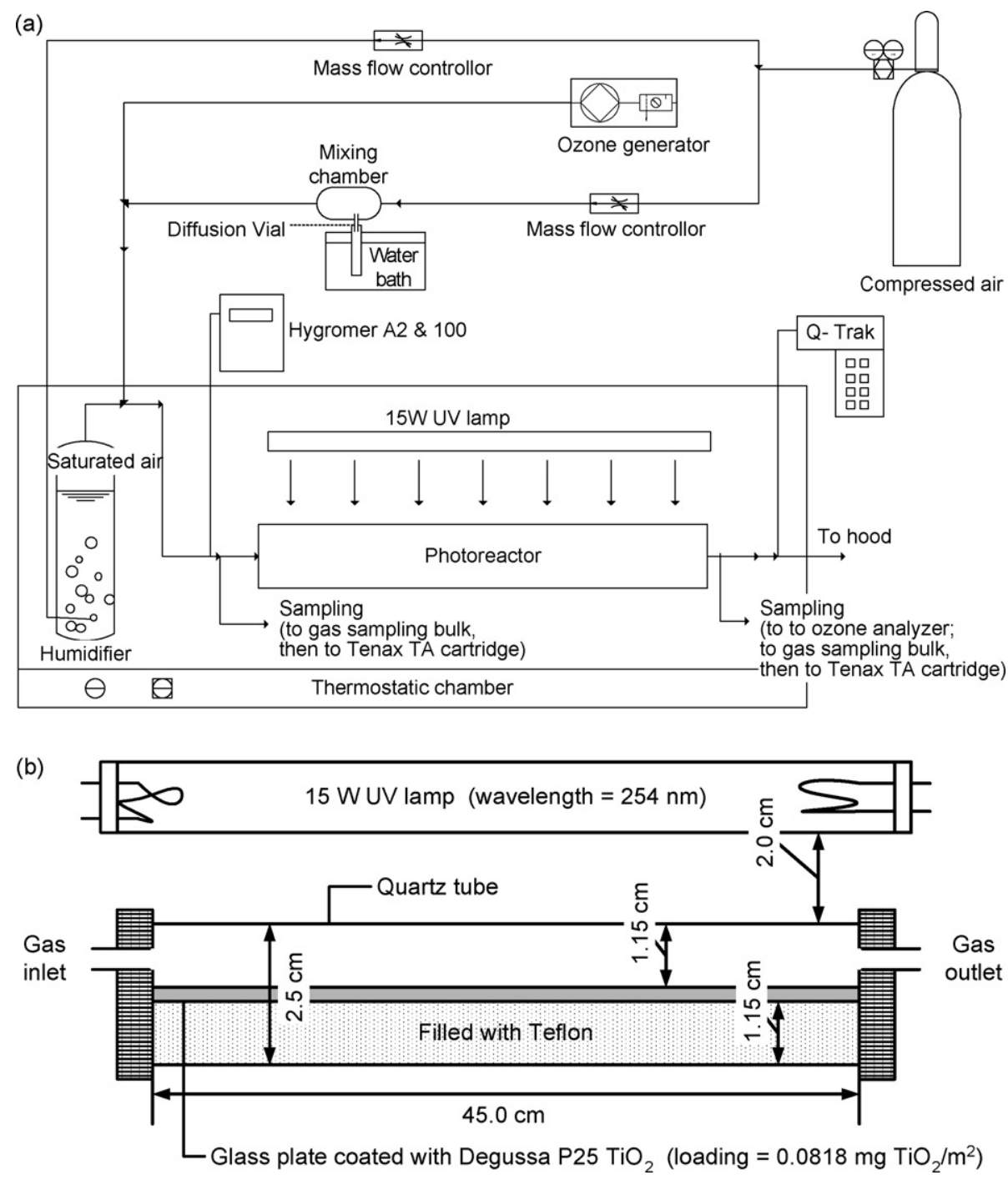

Fig. 1. Schematic diagram of (a) experimental system and (b) photoreactor. 
$\left(0.0818 \mathrm{mg} / \mathrm{cm}^{2}\right)$ in the middle of the quartz tube. To make the gas pass only through the upper part of the tube, the lower half part of the quartz tube was filled with Teflon, as shown in Fig. 1(b). The UV lamp used to illuminate the photocatalyst was a $15-\mathrm{W}, \mathrm{UV}-\mathrm{C}$ (the central wavelength is $254 \mathrm{~nm}$ ), long-life strip light bulb (Philips). The gas of the reaction system was supplied by a compressed gas cylinder of air $\left(21 \% \mathrm{O}_{2}\right.$ and $79 \%$ $\mathrm{N}_{2}$ ) and the gas flow rates were controlled by mass flow controllers (Sierra Instruments Inc.). Toluene (Assay 99.7\%, Riedel-deHaën) was selected as the tested VOC. The toluene vapor was generated from the diffusion vials (VICI Metronics) and the toluene concentration was depended on the temperature of the diffusion vial and the flow rate of dilution air. The relative humidity of the experimental system was controlled by the ratio of the dry and saturated air flow rate. The temperature of the reaction system was controlled at $25 \pm 0.5^{\circ} \mathrm{C}$ by a thermostatic chamber (DENG TNG Instruments Co., Ltd.). We used a Hygromer A2 \& 100A to monitor the temperature and relative humidity of the inlet gas. The ozone generator used was an OZONAIR model RXO-5 ozone generator. Ozone Analyzer Model 400A (API Inc.) was used to monitor the ozone concentration at the outlet of the photoreactor. The Q-Trak 8551 (TSI.) was used to monitor the $\mathrm{CO}_{2}$ and $\mathrm{CO}$ concentrations. Gas samples were taken at the inlet and the outlet of the photoreactor with a $125-\mathrm{mL}$ gas sampling bulk (SUPELCO) and a SKC personal sampling pump. Then, the gas sample in the gas sampling bulk was purged by compressed air with a flow rate of $25 \mathrm{~mL} / \mathrm{min}$ for $10 \mathrm{~min}$ and the eluate was sampled on Tenax TA (60/80 mesh) cartridges (SUPELCO). After sampling, the Tenax TA cartridges were thermal desorbed and cryofocussed by TEKMAR 6000 Aero trap Desorber and then analyzed by GC-FID (HP5890 series II) to determine the toluene concentration of the gas sample. Because Tenax TA was found to react with ozone, the calibration curve of toluene was created under different background $\mathrm{O}_{3}$ concentrations to eliminate the impact of $\mathrm{O}_{3}$-Tenax reaction.

\subsection{Experimental setup}

There were three experimental sets $\left(\mathrm{TiO}_{2} / \mathrm{UV}, \mathrm{TiO}_{2} / \mathrm{UV} / \mathrm{O}_{3}\right.$, and $\mathrm{UV} / \mathrm{O}_{3}$ ) conducted in this study. The $\mathrm{TiO}_{2} / \mathrm{UV} / \mathrm{O}_{3}$ and $\mathrm{TiO}_{2} / \mathrm{UV}$ experiments were conducted with and without the ozone generator operating, respectively. During the $\mathrm{UV} / \mathrm{O}_{3}$ experiments, we used a glass plate without coated $\mathrm{TiO}_{2}$ instead of the original $\mathrm{TiO}_{2}$-coated one (see Fig. 1(b)). The experimental data were collected under steady states. It took $30 \mathrm{~min}$ to $1 \mathrm{~h}$ for the experimental system to reach a steady state after the experiment started. The experiments were conducted under different gas flow rates $(200-1200 \mathrm{~mL} / \mathrm{min})$, toluene concentrations (1-9 ppm), relative humidity (5-80\%), and ozone concentrations (3500-15,000 ppb).

The toluene oxidation rates (TORs) of $\mathrm{TiO}_{2} / \mathrm{UV} / \mathrm{O}_{3}$ and $\mathrm{TiO}_{2} / \mathrm{UV}$ reactions are calculated by Eq. (1), and the TORs of $\mathrm{UV} / \mathrm{O}_{3}$ reaction by Eq. (2):

$\mathrm{TOR}=\frac{\left(C_{\text {in }}-C_{\text {out }}\right) Q}{F \times A}$
$\mathrm{TOR}=\frac{\left(C_{\text {in }}-C_{\text {out }}\right) Q}{F \times V}$

where $C_{\text {in }}$ and $C_{\text {out }}(\mathrm{ppm})$ are the inlet and outlet toluene concentrations, respectively; $Q\left(\mathrm{~m}^{3} / \mathrm{s}\right)$ is the gas flow rate; $F$ is the conversion factor $(=24,500 \mathrm{ppm} \mathrm{m} / \mathrm{mol}$; this is derived from the fact that $\left.1 \mathrm{ppm}=4.09 \times 10^{-5} \mathrm{~mol} / \mathrm{m}^{3}\right) ; A\left(\mathrm{~m}^{2}\right)$ is the $\mathrm{TiO}_{2}$ coating area; $V\left(\mathrm{~m}^{3}\right)$ is the volume of the photoreactor.

The $\mathrm{CO}_{2}$ yield rate is calculated by the following equation:

$\mathrm{CO}_{2}$ yield rate $=\frac{C_{\mathrm{CO}_{2}}(\text { on })-C_{\mathrm{CO}_{2}}(\text { off })}{V / Q}$

where $C_{\mathrm{CO}_{2}}$ (on) and $C_{\mathrm{CO}_{2}}$ (off) (ppm) are the $\mathrm{CO}_{2}$ concentrations observed at the outlet of the photoreactor by the Q-Trak, when the UV lamp was on and off, respectively; $V\left(\mathrm{~m}^{3}\right)$ is the volume of the photoreactor; $Q\left(\mathrm{~m}^{3} / \mathrm{s}\right)$ is the gas flow rate; $V / Q$ (s) is the gas retention time of the photoreactor, which represents the average time for a gas molecule to pass through the photoreactor.

The CO yield rate is calculated by Eq. (4):

CO yield rate $=\frac{C_{\mathrm{CO}}(\text { on })-C_{\mathrm{CO}}(\text { off })}{V / Q}$

in which $C_{\mathrm{CO}}$ (on) and $C_{\mathrm{CO}}$ (off) (ppm) are the $\mathrm{CO}_{2}$ concentrations observed at the outlet of the photoreactor by the Q-Trak, when the UV lamp was on and off, respectively; $V\left(\mathrm{~m}^{3}\right)$ is the volume of the photoreactor; $Q\left(\mathrm{~m}^{3} / \mathrm{s}\right)$ is the gas flow rate; $V / Q$ (s) is the gas retention time of the photoreactor.

\section{Results and discussions}

\subsection{Effect of toluene concentration}

Fig. 2(a) represents the effects of toluene concentration on the $\mathrm{TiO}_{2} / \mathrm{UV}, \mathrm{TiO}_{2} / \mathrm{UV} / \mathrm{O}_{3}$, and $\mathrm{UV} / \mathrm{O}_{3}$ reactions. The TORs of $\mathrm{TiO}_{2} / \mathrm{UV}, \mathrm{TiO}_{2} / \mathrm{UV} / \mathrm{O}_{3}$, and $\mathrm{UV} / \mathrm{O}_{3}$ reactions increased with the toluene concentrations, but the toluene removal efficiency decreased when the toluene concentrations increased. The $\mathrm{CO}_{2}$ yield rates of $\mathrm{TiO}_{2} / \mathrm{UV}$ and $\mathrm{TiO}_{2} / \mathrm{UV} / \mathrm{O}_{3}$ reactions increased with the toluene concentrations, however, the gap between the TORs and $\mathrm{CO}_{2}$ yield rates rose with the toluene concentrations, as shown in Fig. 2(a). It indicates that some partial oxidized compounds (intermediates) were not mineralized to $\mathrm{CO}_{2}$ and $\mathrm{H}_{2} \mathrm{O}$ in the $\mathrm{TiO}_{2} / \mathrm{UV}$ and $\mathrm{TiO}_{2} / \mathrm{UV} / \mathrm{O}_{3}$ reactions. The intermediates yield rate (IYR) based on carbon balance can be calculated by the following equation:

$\mathrm{IYR}=\mathrm{TOR} \times 84-\mathrm{CYR} \times \frac{V \times 12}{F \times A}$

where TOR is the toluene oxidation rate; 84 is the weight of carbon per molecule of toluene; CYR is the $\mathrm{CO}_{2}$ yield rate; $V$ $\left(\mathrm{m}^{3}\right)$ is the volume of the photoreactor; $F$ is the conversion factor $(=24,500 \mathrm{ppm} \mathrm{m} / \mathrm{mol}) ; A\left(\mathrm{~m}^{2}\right)$ is the $\mathrm{TiO}_{2}$ coating area. As shown in Fig. 2(a), the IYRs of $\mathrm{TiO}_{2} / \mathrm{UV}$, and $\mathrm{TiO}_{2} / \mathrm{UV} / \mathrm{O}_{3}$ reactions both rose with the toluene concentrations. The IYRs of $\mathrm{TiO}_{2} / \mathrm{UV}$ reaction were smaller than those of $\mathrm{TiO}_{2} / \mathrm{UV} / \mathrm{O}_{3}$ reaction when the toluene concentration $\geq 5 \mathrm{ppm}$. The IYRs of 


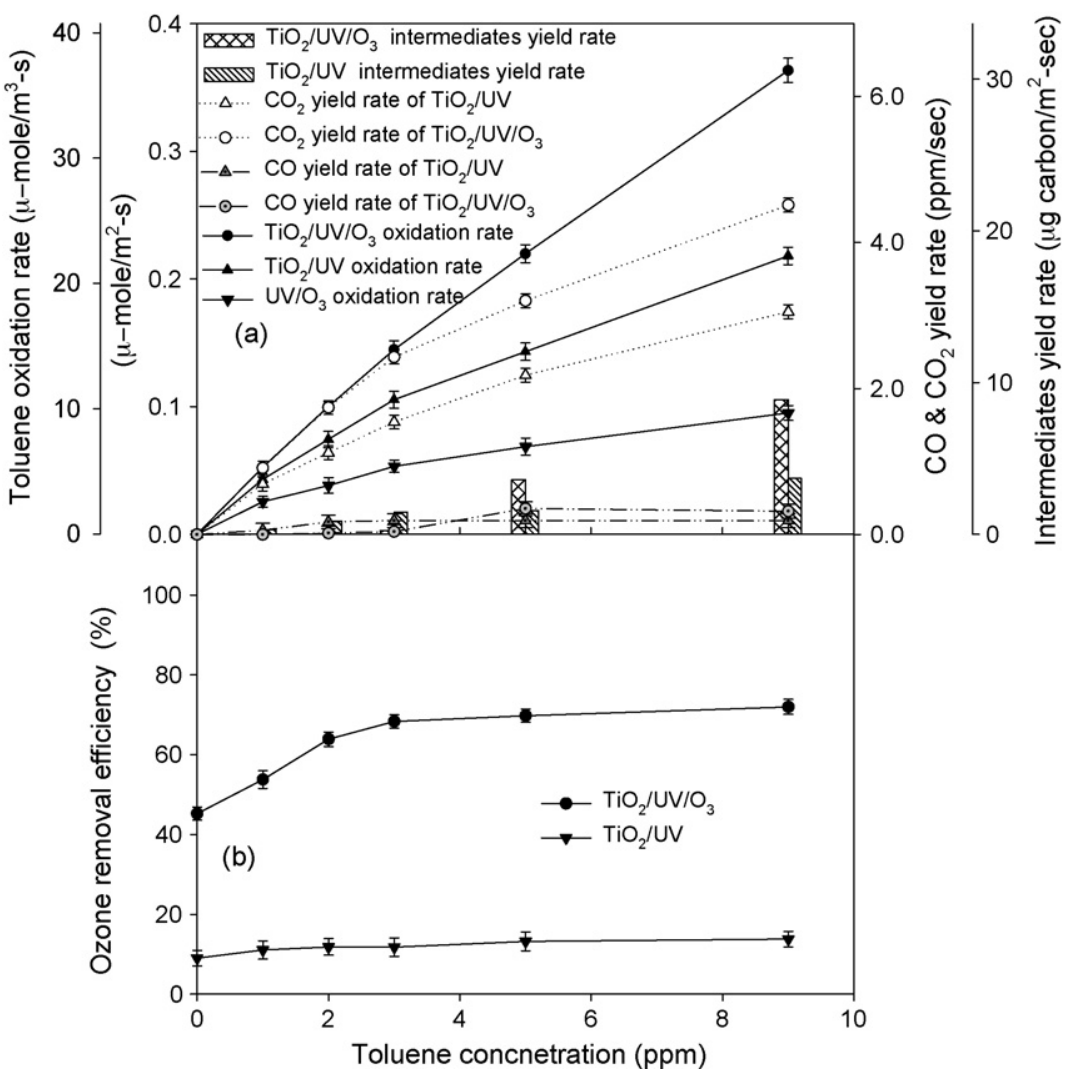

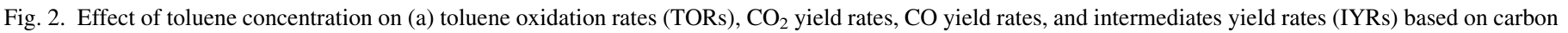

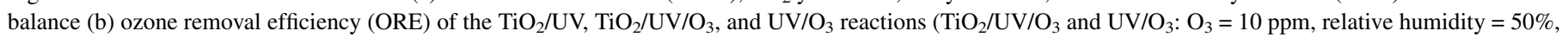
gas flow rate $=1200 \mathrm{~mL} / \mathrm{min}$, retention time: $5.3 \mathrm{~s}, \mathrm{TiO}_{2} / \mathrm{UV}$ : relative humidity $=50 \%$, gas flow rate $=1200 \mathrm{~mL} / \mathrm{min}$, retention time: $5.3 \mathrm{~s}$ ).

$\mathrm{TiO}_{2} / \mathrm{UV} / \mathrm{O}_{3}$ reaction were very small $\left(\leq 0.046 \mu \mathrm{g} / \mathrm{m}^{2}-\mathrm{s}\right)$ and had no obvious variation when the toluene concentration $\leq 2 \mathrm{ppm}$, and increased with the toluene concentrations when the toluene concentration $>2 \mathrm{ppm}$. This result denotes that when the inlet toluene concentration was below $2 \mathrm{ppm}$, the partial oxidized compounds were almost totally mineralized to $\mathrm{CO}_{2}$ and $\mathrm{H}_{2} \mathrm{O}$. However, as the inlet toluene concentration was higher than $2 \mathrm{ppm}$, the amount of partial oxidized compounds increased with the toluene concentration. According to the previous study, the partial oxidized compounds of gas-phase photocatalytic oxidation of toluene consisted of benzaldehyde, benzonic acid, and benzyl alcohol $[12,13]$. Some carbon deposits may be formed on the surface of $\mathrm{TiO}_{2}$ through the polymerization of intermediate radicals [24]. The accumulation of benzonic acid and carbon deposits on the surface of photocatalyst can inhibit the catalytic activity of photocatalyst $[13,24]$. CO was also considered as an intermediate here. The $\mathrm{CO}$ yield rates of $\mathrm{TiO}_{2} / \mathrm{UV}$ and $\mathrm{TiO}_{2} / \mathrm{UV} / \mathrm{O}_{3}$ reactions increased from 0.06 to 0.19 and from 0 to $0.32 \mathrm{ppm} / \mathrm{s}$ as the toluene concentrations increased from 1 to $9 \mathrm{ppm}$.

The ozone removal efficiency (ORE) of $\mathrm{TiO}_{2} / \mathrm{UV} / \mathrm{O}_{3}$ reaction increased from 45.2 to $72 \%$ when the toluene concentration increased from 0 to $9 \mathrm{ppm}$, and there was a turning point of the slope at around 3-ppm toluene concentration (the slope before and after 3 ppm were 7.93 and $0.6 \%$ ORE/ ppm of toluene, respectively). The turning point of the slope of ORE was near the point where the IYRs started to increase, indicating that the accumulation of the partial oxidized compounds on the surface of photocatalyst might inhibit the ozone decomposition by PCO.

The ORE of $\mathrm{UV} / \mathrm{O}_{3}$ reaction increased slightly from 11.1 to $13.8 \%$ when the toluene concentration rose from 1 to $9 \mathrm{ppm}$, thus, the effect of toluene concentration on the ORE of $\mathrm{UV} / \mathrm{O}_{3}$ reaction was insignificant.

\subsubsection{Kinetics of $\mathrm{TiO}_{2} / \mathrm{UV}$ and $\mathrm{TiO}_{2} / \mathrm{UV} / \mathrm{O}_{3}$ reactions}

We assumed that the $\mathrm{TiO}_{2} / \mathrm{UV}$ and $\mathrm{TiO}_{2} / \mathrm{UV} / \mathrm{O}_{3}$ reactions were not gas-phase-mass-transfer limiting at $1200 \mathrm{~mL} / \mathrm{min}$ gas flow rate discussed in Section 3.2, and the kinetics of $\mathrm{TiO}_{2} / \mathrm{UV}$ and $\mathrm{TiO}_{2} / \mathrm{UV} / \mathrm{O}_{3}$ reactions can be described by the LangmuirHinshlwood $(\mathrm{L}-\mathrm{H})$ rate form:

$r=\frac{Q}{W} \times \frac{d C_{\text {toluene }}}{d L}=-\frac{k K C_{\text {toluene }}}{1+K C_{\text {toluene }}}$

where $r$ is the toluene oxidation rate; $Q$ is the gas flow rate; $W$ is the width of the $\mathrm{TiO}_{2}$-coated glass plate; $C_{\text {toluene }}$ is the toluene concentration; $L$ is the length of the photoreactor; $k$ is the $\mathrm{L}-\mathrm{H}$ rate coefficient of $\mathrm{TiO}_{2} / \mathrm{UV}$ and $\mathrm{TiO}_{2} / \mathrm{UV} / \mathrm{O}_{3}$ reactions; $K$ is the Langmuir adsorption constant.

Integrating both sides of Eq. (6), we have:

$$
\frac{A / Q}{\left(C_{\text {in }}-C_{\text {out }}\right)}=\frac{1}{k K} \times \frac{\ln \left(C_{\text {in }} / C_{\text {out }}\right)}{\left(C_{\text {in }}-C_{\text {out }}\right)}+\frac{1}{k}
$$




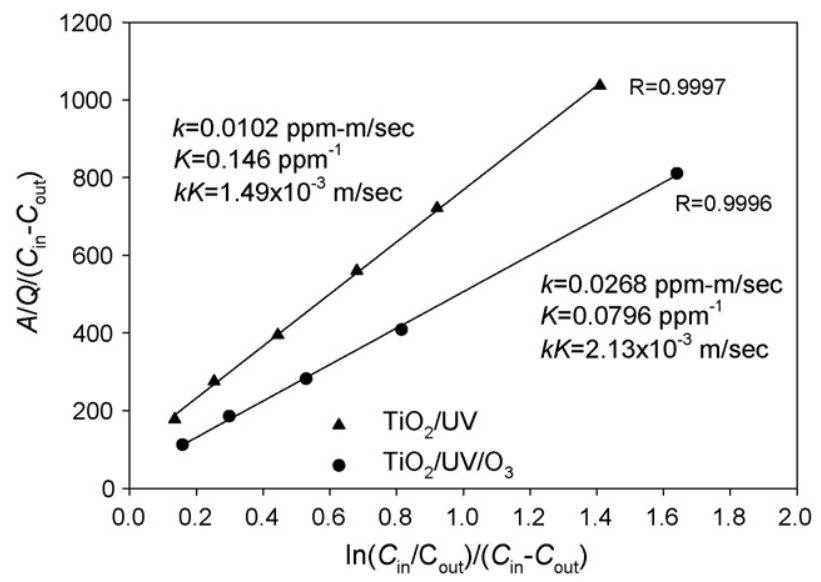

Fig. 3. Plot of $\mathrm{A} / \mathrm{Q} /\left(C_{\text {in }}-C_{\text {out }}\right)$ vs. $\ln \left(C_{\text {in }} / C_{\text {out }}\right) /\left(C_{\text {in }}-C_{\text {out }}\right) \quad\left(\mathrm{TiO}_{2} / \mathrm{UV}\right.$ : toluene $=1-9 \mathrm{ppm}$, relative humidity $=50 \%$, gas flow rate $=1200 \mathrm{~mL} / \mathrm{min}$, $\mathrm{TiO}_{2} / \mathrm{UV} / \mathrm{O}_{3}$ : toluene $=1-9 \mathrm{ppm}, \mathrm{O}_{3}=10 \mathrm{ppm}$, relative humidity $=50 \%$, gas flow rate $=1200 \mathrm{~mL} / \mathrm{min}$, retention time: $5.3 \mathrm{~s}$ ).

in which $C_{\text {in }}$ and $C_{\text {out }}(\mathrm{ppm})$ are the inlet and outlet toluene concentrations, respectively; $A\left(\mathrm{~m}^{2}\right)$ is the $\mathrm{TiO}_{2}$ coating area.

The assumption that the kinetics of $\mathrm{TiO}_{2} / \mathrm{UV}$ and $\mathrm{TiO}_{2} / \mathrm{UV} /$ $\mathrm{O}_{3}$ reactions fits the $\mathrm{L}-\mathrm{H}$ rate form was authenticated by the experiments, since the plots of $\ln \left(C_{\text {in }} / C_{\text {out }}\right) /\left(C_{\text {in }}-C_{\text {out }}\right)$ versus $A / Q /\left(C_{\text {in }}-C_{\text {out }}\right)$ are linear with a positive intercept of $1 / k$ as shown in Fig. 3, and the correlation coefficients $(R)$ of the regression lines of the $\mathrm{TiO}_{2} / \mathrm{UV}$ and $\mathrm{TiO}_{2} / \mathrm{UV} / \mathrm{O}_{3}$ experimental data are 0.9997 and 0.9996 , respectively. The values of $k$ and $K$ are shown in Fig. 3.

\subsection{Effect of gas flow rate}

The TORs and $\mathrm{CO}_{2}$ yield rates of $\mathrm{TiO}_{2} / \mathrm{UV} / \mathrm{O}_{3}$, and $\mathrm{TiO}_{2} /$ UV reactions increased with the gas flow rates increasing from
200 to $800 \mathrm{~mL} / \mathrm{min}$ and achieved a plateau when the gas flow rate $\geq 1000 \mathrm{~mL} / \mathrm{min}$, as shown in Fig. 4 . In the heterogeneous $\mathrm{PCO}$ system $\left(\mathrm{TiO}_{2} / \mathrm{UV} / \mathrm{O}_{3}\right.$ and $\mathrm{TiO}_{2} / \mathrm{UV}$ reactions), the ratedetermining step was the gas-phase mass transfer, or surface reaction, or both of them, and there was no limited pore diffusion. In the region of lower gas flow rate $(200-800 \mathrm{~mL} /$ $\mathrm{min}$ ), the apparent toluene oxidation rate was dependant upon the gas-phase mass transfer rate which increased with the gas flow rate. When the gas flow rate was higher than $1000 \mathrm{~mL} / \mathrm{min}$, the rate-determining step became the surface reaction. The mass transfer of toluene to the wall of the straight tube can be described by the semiempirical Lévêque equation:

$S h=1.615\left(\operatorname{Re} \times S \operatorname{ch} \times \frac{d}{L}\right)^{1 / 3}=\frac{k_{g \text {-toluene }} \times d}{D_{\text {toluene }}}$

in which $S h$ is the Sherwood number; $R e$ is the Reynolds number; $S c h$ is the Schmidt number; $d$ is the hydraulic diameter; $L$ is the length of the photoreactor; $k_{g \text {-toluene }}$ is the mass transfer coefficient of toluene; $D_{\text {toluene }}$ is the diffusivity of toluene in the air $[15,25]$. At $1200-\mathrm{mL} / \mathrm{min}$ gas flow rate, the mass transfer coefficient of toluene ( $\left.k_{g \text {-toluene }}\right)$ equaled to $1.58 \times 10^{-3} \mathrm{~m} / \mathrm{s}$, which was larger than the product of the Langmuir adsorption constant $(K)$ and the $\mathrm{L}-\mathrm{H}$ rate coefficient (k) of $\mathrm{TiO}_{2} / \mathrm{UV}$ reaction $\left(k K=1.49 \times 10^{-3} \mathrm{~m} / \mathrm{s}\right)$ and smaller than that of $\mathrm{TiO}_{2} / \mathrm{UV} / \mathrm{O}_{3}$ reaction $\left(k K=2.13 \times 10^{-3} \mathrm{~m} / \mathrm{s}\right)$. Therefore, the rate-determining steps of $\mathrm{TiO}_{2} / \mathrm{UV}$ and $\mathrm{TiO}_{2} /$ $\mathrm{UV} / \mathrm{O}_{3}$ reactions should be the surface reaction and gas-phase mass transfer, respectively. The experimental result presented in Fig. 4 supported this inferential expectation.

The IYRs of $\mathrm{TiO}_{2} / \mathrm{UV} / \mathrm{O}_{3}$ and $\mathrm{TiO}_{2} / \mathrm{UV}$ reactions increased from 1.01 to $3.63 \mu \mathrm{g}$-carbon $/ \mathrm{m}^{2}$-s and from 0.97 to $2.35 \mu \mathrm{g}$ carbon $/ \mathrm{m}^{2}$-s, respectively, when the gas flow rate increased from 200 to $1200 \mathrm{~mL} / \mathrm{min}$. The $\mathrm{CO}$ yield rate of $\mathrm{TiO}_{2} / \mathrm{UV}$

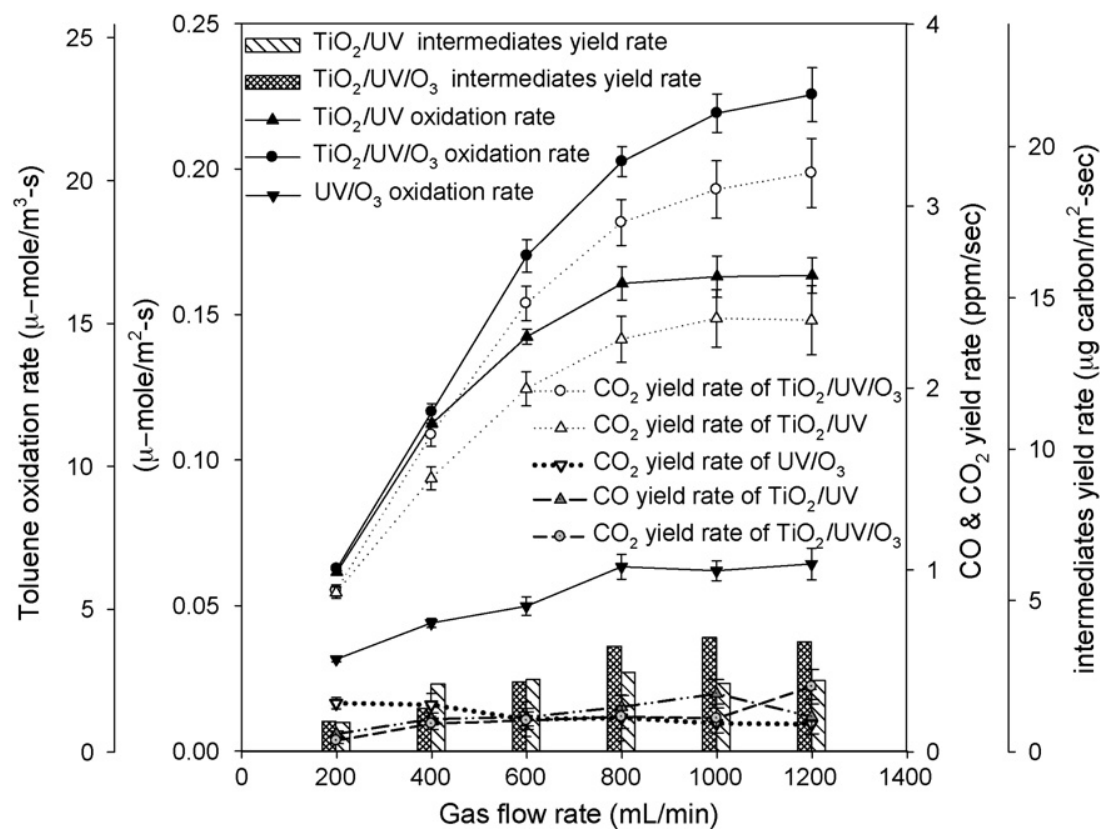

Fig. 4. Effect of gas flow rate on toluene oxidation rates (TORs), $\mathrm{CO}_{2}$ yield rates, $\mathrm{CO}$ yield rates, and intermediates yield rates (IYRs) based on carbon balance (TiO $/$ $\mathrm{UV}$ : toluene $=5 \mathrm{ppm}$, relative humidity $=50 \%, \mathrm{TiO}_{2} / \mathrm{UV} / \mathrm{O}_{3}$ and $\mathrm{UV} / \mathrm{O}_{3}: \mathrm{O}_{3}=10 \mathrm{ppm}$, toluene $=5 \mathrm{ppm}$, relative humidity $=50 \%$ ). 


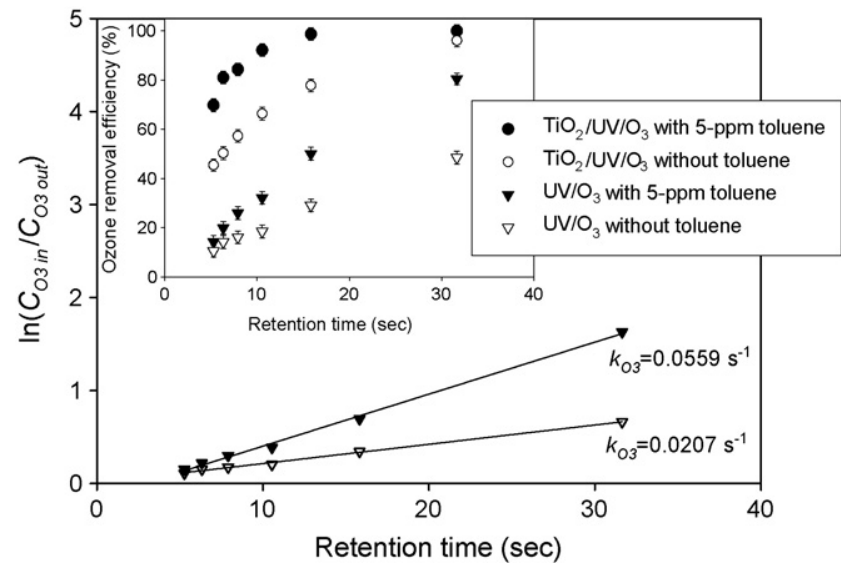

Fig. 5. Plot of retention time vs. $\ln \left(C_{\mathrm{O} 3 \text { in }} / C_{\mathrm{O} 3 \text { out }}\right)\left(C_{\mathrm{O} 3 \text { in }}\right.$ and $C_{\mathrm{O} 3 \text { out }}$ are the inlet and outlet concentration of ozone, respectively) and effect of retention time on ozone removal efficiency $\left(\mathrm{O}_{3}=10 \mathrm{ppm}\right.$, relative humidity $=50 \%$, gas flow rate $=200-1200 \mathrm{~mL} / \mathrm{min})$

reaction increased from 0.09 to $0.32 \mathrm{ppm} / \mathrm{s}$ as the gas flow rate increased from 200 to $1000 \mathrm{~mL} / \mathrm{min}$, and then it decreased to $0.18 \mathrm{ppm} / \mathrm{s}$ when the gas flow rate increased from 1000 to $1200 \mathrm{~mL} / \mathrm{min}$. The decrease of the $\mathrm{CO}$ yield rate may result from the decrease of retention time. The $\mathrm{CO}$ yield rate of $\mathrm{TiO}_{2} /$ $\mathrm{UV} / \mathrm{O}_{3}$ reaction increased from 0.06 to $0.35 \mathrm{ppm} / \mathrm{s}$ when the gas flow rate increased from 200 to $1200 \mathrm{~mL} / \mathrm{min}$.

The TORs of $\mathrm{UV} / \mathrm{O}_{3}$ reactions increased when the gas flow rate increased from 200 to $800 \mathrm{~mL} / \mathrm{min}$ and did not vary with the gas flow rate thereafter. The $\mathrm{UV} / \mathrm{O}_{3}$ reaction is a homogeneous reaction, thus, there was no gas-phase mass transfer effect in this reaction. However, the gas retention time is inversely proportional to the gas flow rate. At lower gas flow rate (longer gas retention time), the toluene conversion was higher and the average toluene concentration in the photoreactor was relatively low. Since the TOR increased with the toluene concentration, lower TOR was expected at lower gas flow rate. This effect became insignificant when the gas flow rate was higher than $1000 \mathrm{~mL} / \mathrm{min}$, because the difference in the average toluene concentration between the 1000- and $1200-\mathrm{mL} / \mathrm{min}$ gas flow rates was smaller than $0.2 \mathrm{ppm}$. This effect also existed in the $\mathrm{TiO}_{2} / \mathrm{UV}$ and $\mathrm{TiO}_{2} / \mathrm{UV} / \mathrm{O}_{3}$ reactions and it became insignificant when the gas flow rate was above $1000 \mathrm{~mL} / \mathrm{min}$.

The ORE of $\mathrm{TiO}_{2} / \mathrm{UV} / \mathrm{O}_{3}$ and $\mathrm{UV} / \mathrm{O}_{3}$ reactions increased with the gas retention time, as shown in Fig. 5. For the $\mathrm{UV} / \mathrm{O}_{3}$ reaction, the gas retention time is linear to the $\ln \left(C_{\mathrm{O} \text { in }} / C_{\mathrm{O} \text { out }}\right)$, in which $C_{\mathrm{O} 3 \text { in }}$ and $C_{\mathrm{O} \text { out }}$ are the inlet and outlet ozone concentrations, respectively. Therefore, the $\mathrm{O}_{3}$ removal of $\mathrm{UV} /$ $\mathrm{O}_{3}$ reaction was first-order rate form. The rate constants calculated from the regression are shown in Fig. 5(a).

\subsection{Effect of humidity}

The effect of humidity on the $\mathrm{TiO}_{2} / \mathrm{UV} / \mathrm{O}_{3}, \mathrm{TiO}_{2} / \mathrm{UV}$, and $\mathrm{UV} / \mathrm{O}_{3}$ reactions are shown in Fig. 6(a). The TORs of $\mathrm{TiO}_{2} / \mathrm{UV}$ reaction increased from 0.068 to $0.15 \mu-\mathrm{mol} / \mathrm{m}^{2}-\mathrm{s}$ when the

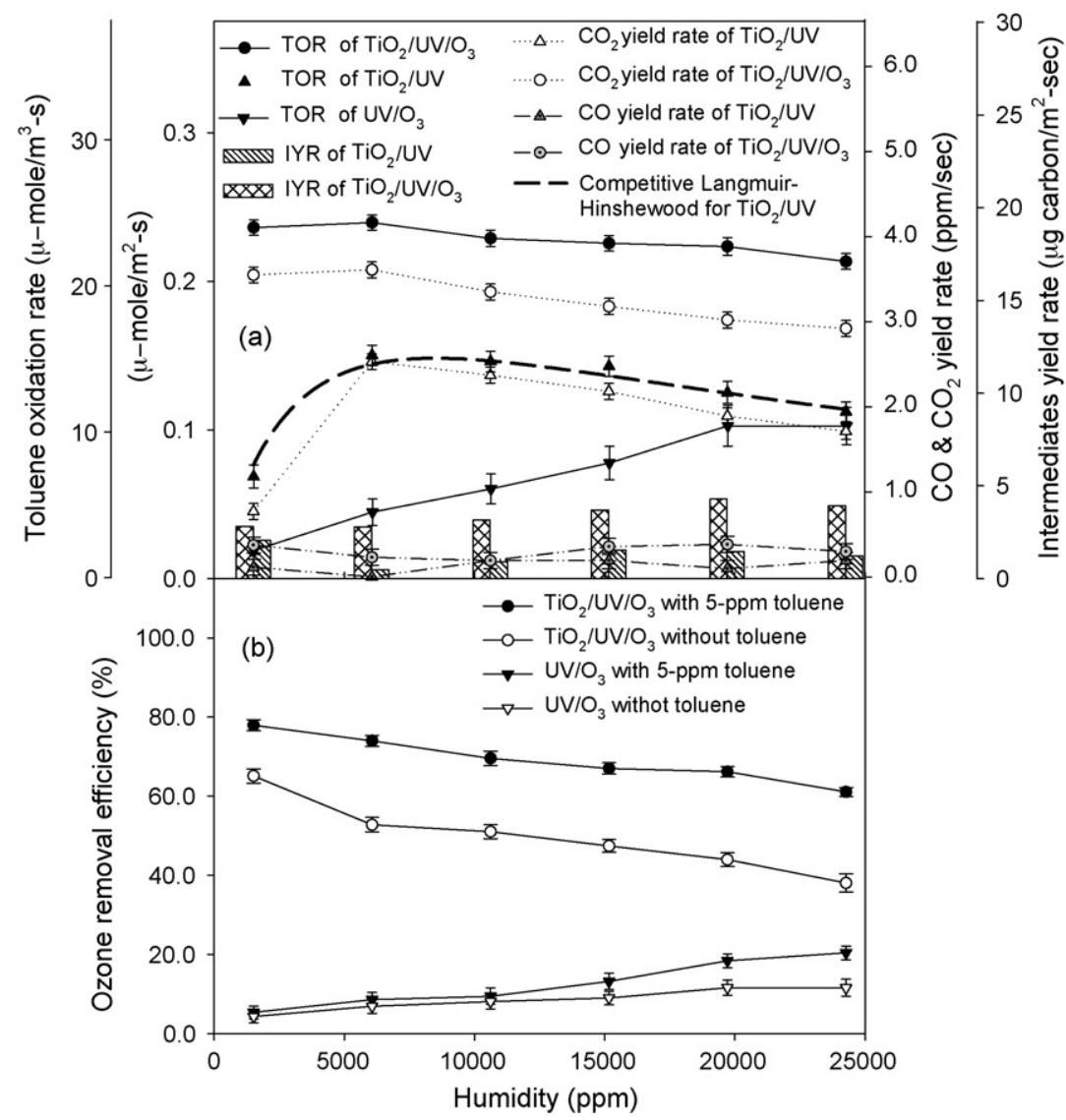

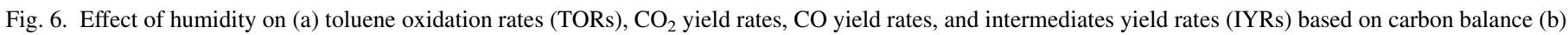
ozone removal efficiency $\left(\mathrm{O}_{3}=10 \mathrm{ppm}\right.$, toluene $=5 \mathrm{ppm}$, flow rate $=1200 \mathrm{~mL} / \mathrm{min}$, retention time: $\left.5.3 \mathrm{~s}\right)$. 
humidity increased from 1517 to $6070 \mathrm{ppm}$ (relative humidity from 5 to $20 \%$ ), but the TORs dropped from 0.15 to $0.112 \mu$ $\mathrm{mol} / \mathrm{m}^{2}$-s when the humidity went up from 6070 to $24,270 \mathrm{ppm}$ (relative humidity from 20 to $80 \%$ ). This result revealed the dual effect of humidity on the $\mathrm{TiO}_{2} / \mathrm{UV}$ reaction. In the $\mathrm{TiO}_{2} /$ UV reaction, $\mathrm{H}_{2} \mathrm{O}$ molecules were essential for the generation of hydroxyl radicals. No $\mathrm{CO}_{2}$ evolution in the photocatalytic degradation of toluene was found in the absence of humidity $[6,26]$. However, the toluene molecules confronted the competition from $\mathrm{H}_{2} \mathrm{O}$ molecules for the adsorption sites on the surface of $\mathrm{TiO}_{2}$ [27]. Therefore, the increase of humidity showed a positive effect when the humidity was smaller than $6070 \mathrm{ppm}$ and showed a negative effect when the humidity was higher than $6070 \mathrm{ppm}$ on the TORs of $\mathrm{TiO}_{2} / \mathrm{UV}$ reaction. A competitive $\mathrm{L}-\mathrm{H}$ model can be used to describe the effects of relative humidity on the $\mathrm{TiO}_{2} / \mathrm{UV}$ reaction [27]:

$r=\frac{k_{\text {competitive }} K_{1} C_{\text {toluene }} K_{2} C_{w}}{\left(1+K_{1} C_{\text {toluene }}+K_{2} C_{w}\right)^{2}}$

where $r\left(\mu-\mathrm{mol} \mathrm{m}^{-2} \mathrm{~s}^{-1}\right)$ is the toluene oxidation rate; $k_{\text {compe- }}$ titive $\left(\mu-\mathrm{mol} \mathrm{m}^{-2} \mathrm{~s}^{-1}\right)$ is the rate coefficient of competitive $\mathrm{L}-\mathrm{H}$ model; $K_{1}$ and $K_{2}\left(\mathrm{ppm}^{-1}\right)$ are the competitive Langmuir adsorption constants for toluene and $\mathrm{H}_{2} \mathrm{O}$, respectively; $C_{\text {toluene }}$ (ppm) is the toluene concentration; $C_{w}(\mathrm{ppm})$ is the humidity. The best-fit curve of Eq. (9) to experimental data is shown in Fig. 6(a). According to the curve-fitting result, the values of $k_{\text {competitive }}, K_{1}$, and $K_{2}$ are $11.7 \mu-\mathrm{mol} \mathrm{m}^{-2} \mathrm{~s}^{-1}, 0.016 \mathrm{ppm}^{-1}$, and $1 \times 10^{-1} \mathrm{ppm}^{-1}$, respectively.

As shown in Fig. 6(a), the IYRs and $\mathrm{CO}$ yield rates of $\mathrm{TiO}_{2} /$ UV reaction had a minimum value at 6070-ppm humidity, indicating this point that should be the optimum operation condition for the $\mathrm{TiO}_{2} / \mathrm{UV}$ reaction.

The TORs and $\mathrm{CO}_{2}$ yield rates of $\mathrm{TiO}_{2} / \mathrm{UV} / \mathrm{O}_{3}$ reaction decreased from 0.24 to $0.213 \mu-\mathrm{mol} / \mathrm{m}^{2}$-s and from 3.6 to $2.9 \mathrm{ppm} / \mathrm{s}$, respectively, when the humidity increased from 6070 to 24,270 ppm, as shown in Fig. 6(a). Unlike the $\mathrm{TiO}_{2} / \mathrm{UV}$ reaction, when the humidity decreased from 6070 to $1517 \mathrm{ppm}$, the TORs and $\mathrm{CO}_{2}$ yield rates of $\mathrm{TiO}_{2} / \mathrm{UV} / \mathrm{O}_{3}$ reaction dropped slightly from 0.24 to $0.236 \mu-\mathrm{mol} / \mathrm{m}^{2}$-s and 3.6 to $3.5 \mathrm{ppm} / \mathrm{s}$, respectively. Under low humidity or in the absence of humidity, the dominant reaction pathway of the $\mathrm{TiO}_{2} / \mathrm{UV} / \mathrm{O}_{3}$ reaction might be the generation of ${ }^{\bullet} \mathrm{O}^{-}$radical, as shown in the second column of Table 1 . Through this pathway, one $\mathrm{O}_{3}$ molecule and one electron could generate one ${ }^{\bullet} \mathrm{O}^{-}$radical without the involvement of $\mathrm{H}_{2} \mathrm{O}$. The formed ${ }^{\bullet} \mathrm{O}^{-}$radical could oxidize toluene and the partial oxidized compounds continuously.

When the humidity was between 1517 and 24,270 ppm, the IYRs and the $\mathrm{CO}$ yield rates of $\mathrm{TiO}_{2} / \mathrm{UV} / \mathrm{O}_{3}$ reaction ranged from 0.28 to $0.42 \mu \mathrm{g}$ carbon $/ \mathrm{m}^{2}$-s and 0.19 to $0.37 \mathrm{ppm} / \mathrm{s}$, respectively. However, the correlations between humidity and each of the IYR and the CO yield rate were not very obvious.

The increase of humidity revealed a positive effect on the TORs of $\mathrm{UV} / \mathrm{O}_{3}$ reaction, as shown in Fig. 6(a), owing to that water molecule played an important role in the initial step of the $\mathrm{UV} / \mathrm{O}_{3}$ chain reaction $\left(\mathrm{O}_{3}+\mathrm{H}_{2} \mathrm{O} \stackrel{h v}{\longrightarrow} 2 \mathrm{OH}^{\bullet}+\mathrm{O}_{2}\right)$. Therefore, in the $\mathrm{UV} / \mathrm{O}_{3}$ reaction, formation of hydroxyl radicals, the major oxidizer of the $\mathrm{UV} / \mathrm{O}_{3}$ reaction, was favored under high humidity.

The ORE of $\mathrm{UV} / \mathrm{O}_{3}$ reaction increased from 5.3 to $20.4 \%$ (with 5-ppm toluene) and from 4.3 to $11.6 \%$ (without toluene) when the humidity increased from 1517 to $24,270 \mathrm{ppm}$, as shown in Fig. 6(b). This was also relevant to the enhancement effect of humidity on the formation of hydroxyl radicals $\left(\mathrm{OH}^{\bullet}\right)$ in the $\mathrm{UV} / \mathrm{O}_{3}$ chain reaction. The hydroxyl radicals would react with $\mathrm{O}_{3}$ to generate $\mathrm{HO}_{2}{ }^{\bullet}$ radicals and $\mathrm{O}_{2}$, and then the $\mathrm{HO}_{2}{ }^{\bullet}$ radicals would react with $\mathrm{O}_{3}$ to form hydroxyl radical and $\mathrm{O}_{2}$ [1]:

$$
\begin{aligned}
& \mathrm{OH}^{\bullet}+\mathrm{O}_{3} \rightarrow \mathrm{HO}_{2}^{\bullet}+\mathrm{O}_{2} \\
& \mathrm{HO}_{2}^{\bullet}+\mathrm{O}_{3} \rightarrow \mathrm{OH}^{\bullet}+2 \mathrm{O}_{2}
\end{aligned}
$$

In the $\mathrm{TiO}_{2} / \mathrm{UV} / \mathrm{O}_{3}$ reaction, the increase of humidity was unfavorable for the $\mathrm{O}_{3}$ removal. As shown in Fig. 6(b), when the humidity increased from 1517 to $24,270 \mathrm{ppm}$, the ORE of $\mathrm{TiO}_{2} /$ $\mathrm{UV} / \mathrm{O}_{3}$ reaction decreased from 77.9 to $61.1 \%$ and from 65.1 to

Table 1

\begin{tabular}{|c|c|c|}
\hline Reaction type & Reaction steps & Stoichiometry \\
\hline $\mathrm{TiO}_{2} / \mathrm{UV}$ & $\begin{array}{l}\mathrm{TiO}_{2}+h v \rightarrow \mathrm{TiO}_{2}+e^{-}+h^{+} \\
h^{+}+\mathrm{H}_{2} \mathrm{O} \rightarrow \mathrm{OH}^{\bullet}+\mathrm{H}^{+} \\
h^{+}+\mathrm{OH}^{-} \rightarrow \mathrm{OH}^{\bullet} \\
e^{-}+\mathrm{O}_{2} \rightarrow \mathrm{O}_{2}^{-\bullet} \\
2 \mathrm{O}_{2}^{-\bullet}+2 \mathrm{H}_{2} \mathrm{O} \rightarrow \mathrm{H}_{2} \mathrm{O}_{2}+2 \mathrm{OH}^{-}+\mathrm{O}_{2} \\
\mathrm{H}_{2} \mathrm{O}_{2}+e^{-} \rightarrow \mathrm{OH}^{-}+\mathrm{OH}^{\bullet}\end{array}$ & $3 e^{-}+3 h^{+}+2 \mathrm{H}_{2} \mathrm{O}+\mathrm{O}_{2} \rightarrow 4 \mathrm{OH}^{\bullet}$ \\
\hline $\mathrm{TiO}_{2} / \mathrm{UV} / \mathrm{O}_{3}$ & $\begin{array}{l}\text { Formation of } \mathrm{OH}^{\bullet} \text { radical } \\
\mathrm{TiO}_{2}+h v \rightarrow \mathrm{TiO}_{2}+e^{-}+h^{+} \\
e^{-}+\mathrm{O}_{2} \rightarrow \mathrm{O}_{2}^{-} \\
{ }^{\bullet} \mathrm{O}_{2}^{-}+\mathrm{O}_{3} \rightarrow \mathrm{O}_{2}+{ }^{\bullet} \mathrm{O}_{3}{ }^{-} \\
{ }^{\bullet} \mathrm{O}_{3}^{-}+\mathrm{H}_{2} \mathrm{O} \longrightarrow \mathrm{TiO}_{2} \mathrm{OH}^{\bullet}+\mathrm{OH}^{-}+\mathrm{O}_{2} \\
\mathrm{OH}^{-}+h^{+} \rightarrow \mathrm{OH}^{\bullet} \\
\mathrm{Formation} \mathrm{of}^{\bullet} \mathrm{O}^{-} \text {radical } \\
e^{-}+\mathrm{O}_{2} \rightarrow \mathrm{O}_{2}^{-} \\
{ }^{\bullet} \mathrm{O}_{2}^{-}+\mathrm{O}_{3} \rightarrow \mathrm{O}_{2}+{ }^{\bullet} \mathrm{O}_{3}^{-} \\
{ }^{-} \mathrm{O}_{3}^{-} \longrightarrow \mathrm{TiO}_{2} \cdot \mathrm{O}^{-}+\mathrm{O}_{2}\end{array}$ & $\begin{array}{c}e^{-}+h^{+}+\mathrm{H}_{2} \mathrm{O}+\mathrm{O}_{3} \rightarrow 2 \mathrm{OH}^{\bullet}+\mathrm{O}_{2} \\
e^{-}+\mathrm{O}_{3} \rightarrow{ }^{\bullet} \mathrm{O}^{-}+\mathrm{O}_{2}\end{array}$ \\
\hline
\end{tabular}

Possible reaction mechanisms of the $\mathrm{TiO}_{2} / \mathrm{UV}$ and $\mathrm{TiO}_{2} / \mathrm{UV} / \mathrm{O}_{3}$ reactions $[28,29]$ 


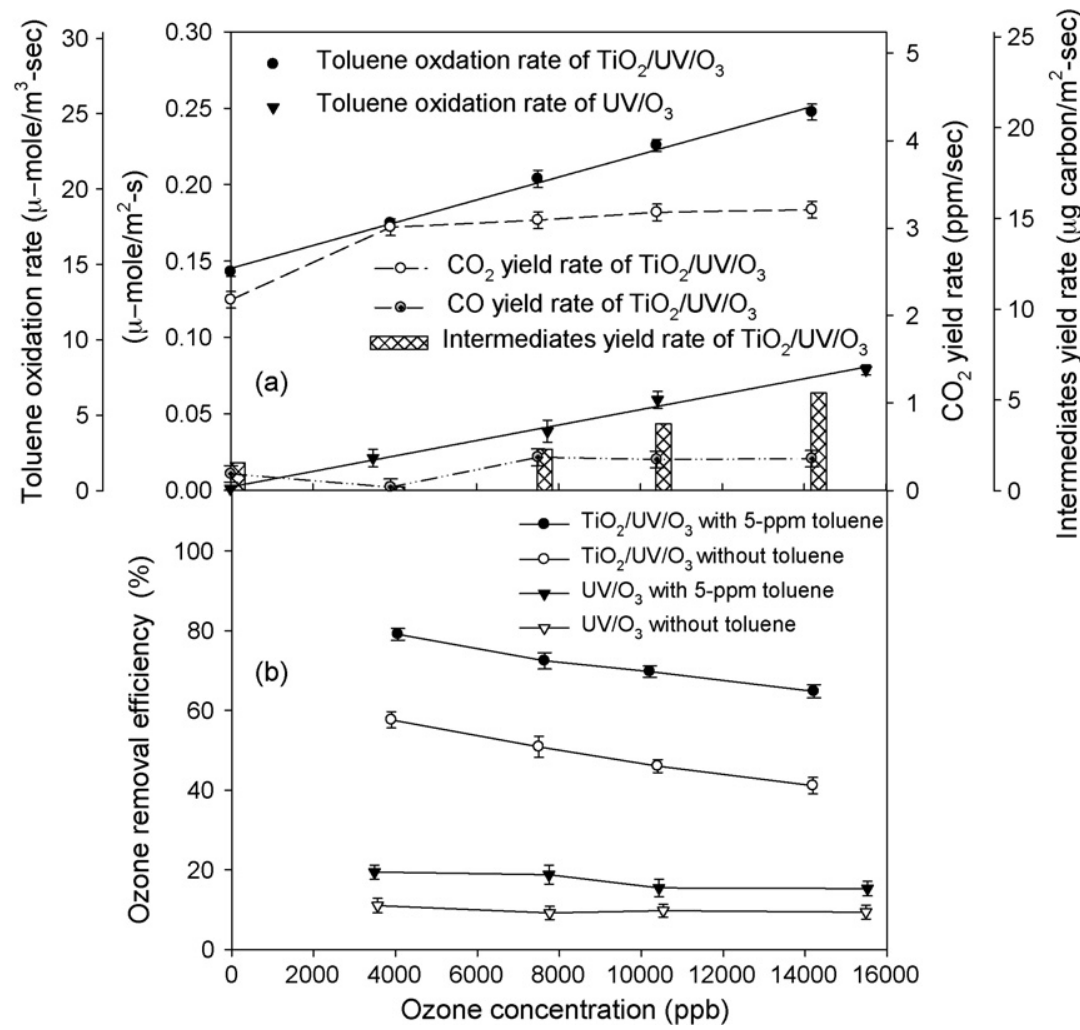

Fig. 7. Effect of ozone concentrations on (a) toluene oxidation rates (TORs), $\mathrm{CO}_{2}$ yield rates, $\mathrm{CO}$ yield rates, and intermediates yield rates (IYRs) based on carbon balance (b) ozone removal efficiency (toluene $=5 \mathrm{ppm}$, relative humidity $=50 \%$, flow rate $=1200 \mathrm{~mL} / \mathrm{min}$, retention time: $5.3 \mathrm{~s}$ ).

$38.1 \%$ in the presence and absence of 5-ppm toluene, respectively. This might result from the competitive adsorption between $\mathrm{O}_{3}$ molecules and $\mathrm{H}_{2} \mathrm{O}$ molecules for the adsorption sites on the surface of $\mathrm{TiO}_{2}$.

\subsection{Effect of ozone concentration}

Fig. 7(a) shows the positive effect of ozone on the TORs of $\mathrm{TiO}_{2} / \mathrm{UV} / \mathrm{O}_{3}$ and $\mathrm{UV} / \mathrm{O}_{3}$ reactions. The TORs of $\mathrm{TiO}_{2} / \mathrm{UV} / \mathrm{O}_{3}$ and $\mathrm{UV} / \mathrm{O}_{3}$ reactions were proportional to the ozone concentrations. The slope of the linear regression line in Fig. 7(a) was defined as the enhancement index of ozone. The enhancement index of ozone of $\mathrm{TiO}_{2} / \mathrm{UV} / \mathrm{O}_{3}$ reaction was $7.49 \times 10^{-6} \mu$-mol-m ${ }^{-2}-\mathrm{s}^{-1} / \mathrm{ppb}-\mathrm{O}_{3}$.

The IYRs and $\mathrm{CO}$ yield rates of $\mathrm{TiO}_{2} / \mathrm{UV} / \mathrm{O}_{3}$ reaction had minimum values (IYR $=0.23 \mu \mathrm{g}$ carbon $/ \mathrm{m}^{2}$-s and $\mathrm{CO}$ yield rate $=0.04 \mathrm{ppm} / \mathrm{s}$ ) at $3.9-\mathrm{ppm}$ ozone concentration.

As shown in Fig. 7(b), the ORE of $\mathrm{TiO}_{2} / \mathrm{UV} / \mathrm{O}_{3}$ reaction ranged from 41.2 to $57.7 \%$ in the absence of toluene and ranged from 69.8 to $79.1 \%$ in the presence of 5-ppm toluene. The ORE decreased when the ozone concentration increased. The kinetics of ozone removal fits the $\mathrm{L}-\mathrm{H}$ rate form as described in Eq. (6) in which the inlet and outlet toluene concentrations replaced by the inlet and outlet ozone concentrations, respectively. The regression line of $\ln \left(C_{\mathrm{O} 3 \text { in }} / C_{\mathrm{O} 3 \text { out }}\right) /\left(C_{\mathrm{O} 3 \text { in }}\right.$ $\left.-C_{\mathrm{O} 3 \text { out }}\right)$ versus $A / Q /\left(C_{\mathrm{O} 3 \text { in }}-C_{\text {O3out }}\right)$ is shown in Fig. 8 and the correlation coefficients $(\mathrm{R})$ of the regression lines with 5ppm toluene and without toluene were 0.9979 and 0.9967, respectively. The $\mathrm{L}-\mathrm{H}$ rate coefficient of ozone $\left(k_{\mathrm{O} 3}\right)$ with and without 5-ppm toluene were 38.9 and $19.7 \mathrm{ppb}-\mathrm{m} / \mathrm{s}$, respectively. And the Langmuir adsorption constant of ozone $\left(K_{\mathrm{O} 3}\right)$ with and without 5-ppm toluene were $8.9 \times 10^{-5}$ and $1.03 \times 10^{-4} \mathrm{ppb}^{-1}$, respectively. The values of $k_{\mathrm{O} 3}$ and $K_{\mathrm{O} 3}$ were calculated on the basis of the regression results.

The enhancement index of ozone of $\mathrm{UV} / \mathrm{O}_{3}$ reaction was $5.82 \times 10^{-4} \mu-\mathrm{mol}-\mathrm{m}^{-3}-\mathrm{s}^{-1} / \mathrm{ppb}^{-\mathrm{O}_{3}} \quad\left(=5.71 \times 10^{-6} \mu\right.$-mol$\mathrm{m}^{-2}-\mathrm{s}^{-1} / \mathrm{ppb}-\mathrm{O}_{3}$ ), which was smaller than that of $\mathrm{TiO}_{2} / \mathrm{UV} /$ $\mathrm{O}_{3}$ reaction. The OREs of $\mathrm{UV} / \mathrm{O}_{3}$ reaction ranged from 15.3 to $19.5 \%$ in the presence of 5-ppm toluene and ranged from 9.2 to

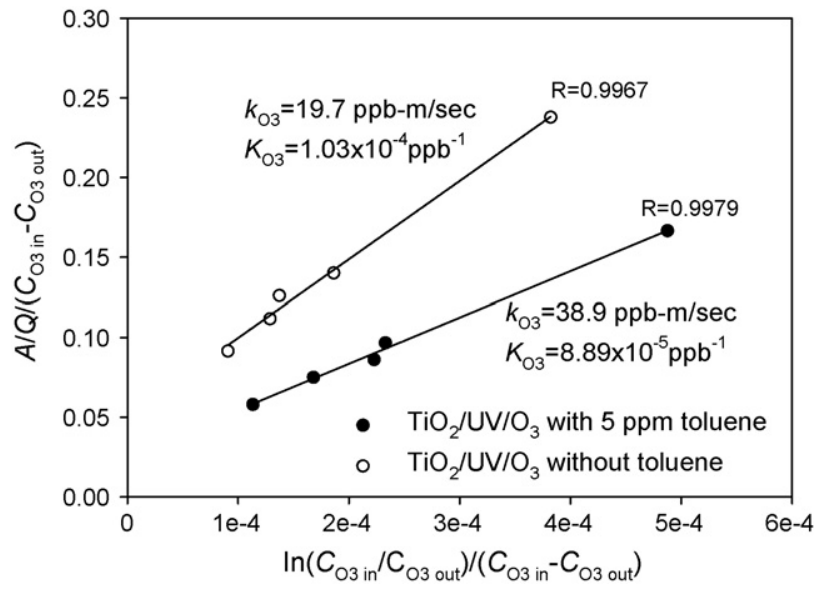

Fig. 8. Plot of $\mathrm{A} / \mathrm{Q} /\left(\mathrm{C}_{\mathrm{O} 3 \text { in }}-\mathrm{C}_{\mathrm{O} \text { 3out }}\right)$ vs. $\ln \left(\mathrm{C}_{\mathrm{O} 3 \text { in }} / \mathrm{C}_{\mathrm{O} \text { out }}\right) /\left(\mathrm{C}_{\mathrm{O} 3 \text { in }}-\mathrm{C}_{\mathrm{O} 3 \text { out }}\right)$ The data points were obtained under gas flow rate of $1000-1200 \mathrm{~mL} / \mathrm{min}$, where the effect of mass transfer was relatively low (relative humidity $=50 \%, \mathrm{O}_{3}=4060$ $14,200 \mathrm{ppb}$, retention time: 5.3-6.33 s). 
$11.1 \%$ in the absence of toluene. The variation of ORE under different ozone concentrations was within $4.2 \%$. This result was consistent with the result in Section 3.2 that the $\mathrm{O}_{3}$ removal of $\mathrm{UV} / \mathrm{O}_{3}$ reaction was first-order rate form.

\subsection{Comparison between $\mathrm{TiO}_{2} / \mathrm{UV}$ and $\mathrm{TiO}_{2} / \mathrm{UV} / \mathrm{O}_{3}$ reactions}

The TORs and $\mathrm{CO}_{2}$ yield rates of $\mathrm{TiO}_{2} / \mathrm{UV} / \mathrm{O}_{3}$ reaction were higher than those of $\mathrm{TiO}_{2} / \mathrm{UV}$ reaction, as shown in Figs. 2(a), 4 and 6(a). The gas-phase $\mathrm{UV} / \mathrm{O}_{3}$ reaction was one of the possible explanations for this result. However, the gap between the TORs of $\mathrm{TiO}_{2} / \mathrm{UV} / \mathrm{O}_{3}$ reaction and $\mathrm{TiO}_{2} / \mathrm{UV}$ reaction was larger than that of $\mathrm{UV} / \mathrm{O}_{3}$ reaction when the toluene concentration was higher than 5 ppm. Furthermore, the $\mathrm{CO}_{2}$ evolution of $\mathrm{UV} / \mathrm{O}_{3}$ reaction was lower than the detection limit of the Q-Trak, indicating that the $\mathrm{CO}_{2}$ yield rate of $\mathrm{UV} / \mathrm{O}_{3}$ reaction was much lower than the gap between the $\mathrm{CO}_{2}$ yield rates of $\mathrm{TiO}_{2} / \mathrm{UV} / \mathrm{O}_{3}$ reaction and $\mathrm{TiO}_{2} /$ UV reaction. The possible reasons for this experimental result were that the ratio of $\left(\mathrm{OH}^{\bullet}\right.$ product)/(electron-hole pairs consumption) of $\mathrm{O}_{3}$ pathway was higher than that of $\mathrm{O}_{2}$ pathway, and the electron affinity of $\mathrm{O}_{3}$ was relatively high $(2.1 \mathrm{eV})$ compared with that of $\mathrm{O}_{2}(0.44 \mathrm{eV})$ [28]. The hydroxyl radicals acted as the primary oxidizer for organic compounds oxidation in the PCO reaction [29-31]. The possible reaction mechanisms of $\mathrm{TiO}_{2} / \mathrm{UV}$ reaction for the hydroxyl radical formation are shown in Table 1. When an electron on the valence band (VB) of semiconductor absorbed a photon with energy higher than the band gap between the VB and the conduction band (CB), it would be promoted to the $\mathrm{CB}$ and thus an electron-hole pair was formed. The holes would oxidize either $\mathrm{H}_{2} \mathrm{O}$ or $\mathrm{OH}^{-}$anions dissociated from water to form hydroxyl radicals. The electrons on the $\mathrm{CB}$ reacted with $\mathrm{O}_{2}$ to generate superoxide ions $\left(\mathrm{O}_{2}{ }^{--}\right)$. Then, the superoxide ions would react with $\mathrm{H}_{2} \mathrm{O}$ to produce added $\mathrm{OH}^{\bullet}$, $\mathrm{OH}^{-}$, and $\mathrm{O}_{2}$. Combining all the reaction steps and equilibrating all elements, we had the stoichiometry of $\mathrm{TiO}_{2} / \mathrm{UV}$ reaction for hydroxyl radical, as shown in the third column of Table 1. According to this stoichiometry, in the presence of humidity, one oxygen molecule and three electron-hole pairs could generate four hydroxyl radicals.

Owing to the higher electron affinity of $\mathrm{O}_{3}$, the excited electrons on the $\mathrm{CB}$ of $\mathrm{TiO}_{2}$ were captured by $\mathrm{O}_{3}$ more easily than by $\mathrm{O}_{2}$. After capturing the electrons, the $\mathrm{O}_{3}$ became $\mathrm{O}_{3}{ }^{\bullet-}$ anion radical. Then, the $\mathrm{O}_{3}^{\bullet-}$ anion radicals rapidly split into $\mathrm{O}^{\bullet-}$ radicals and $\mathrm{O}_{2}$ molecules or reacted with $\mathrm{H}_{2} \mathrm{O}$ to generate $\mathrm{OH}^{\bullet}$ radicals, $\mathrm{OH}^{-}$ions, and $\mathrm{O}_{2}$ molecules. These reaction steps are shown in Table 1 , and the stoichiometry of $\mathrm{TiO}_{2} / \mathrm{UV} /$ $\mathrm{O}_{3}$ reaction for hydroxyl radical was shown in the third column. In accordance with this stoichiometry, one $\mathrm{O}_{3}$ molecule and one electron-hole pair could generate two hydroxyl radicals and one $\mathrm{O}_{2}$ molecule. The ratio of " $\left(\mathrm{OH}^{\bullet}\right.$ product $) /($ electron-hole pairs consumption)" of $\mathrm{O}_{3}$ pathway (equal to 2) was higher than that of $\mathrm{O}_{2}$ pathway (equal to 4/3). Therefore, in the presence of ozone, the photocatalytic reaction could generate more hydroxyl radicals via the $\mathrm{TiO}_{2} / \mathrm{UV} / \mathrm{O}_{3}$ reaction. And these added hydroxyl radicals could enhance the toluene oxidation rates and the $\mathrm{CO}_{2}$-yield rates.

\subsection{Reaction mechanisms and kinetics of $U \mathrm{~V} / \mathrm{O}_{3}$ reaction}

The possible reaction mechanisms of gas-phase $\mathrm{UV} / \mathrm{O}_{3}$ chain reactions are shown as the following equations [1,32]:

$$
\begin{aligned}
& \mathrm{O}_{3}+h \nu \stackrel{1}{\longrightarrow} \mathrm{O}\left({ }^{1} \mathrm{D}\right)+\mathrm{O}_{2} \\
& \mathrm{O}\left({ }^{1} \mathrm{D}\right)+\mathrm{H}_{2} \mathrm{O} \stackrel{2}{\longrightarrow} 2 \mathrm{OH}^{\bullet} \\
& \mathrm{RH}+\mathrm{OH}^{\bullet} \stackrel{3}{\longrightarrow} \mathrm{ROH}_{2} \\
& \quad(\text { Chain initiation, major pathway }(90 \%))
\end{aligned}
$$

$\mathrm{RH}+\mathrm{OH}^{\bullet} \stackrel{4}{\longrightarrow} \mathrm{R}^{\bullet}+\mathrm{H}_{2} \mathrm{O}$

(Chain initiation, minor pathway (10\%))

$\mathrm{ROH}_{2}{ }^{\bullet}+\mathrm{O}_{2} \stackrel{5}{\longrightarrow} \mathrm{Cresol}+\mathrm{HO}_{2}^{\bullet}$

$\mathrm{ROH}_{2} \bullet+\mathrm{O}_{2} \stackrel{6}{\longrightarrow} \mathrm{ROH}_{2} \mathrm{O}_{2}^{\bullet}$

$\mathrm{R}^{\bullet}+\mathrm{O}_{2} \stackrel{7}{\longrightarrow} \mathrm{RO}_{2}^{\bullet}$

$\mathrm{OH}^{\bullet}+$ wall $\stackrel{8}{\longrightarrow}($ Chain termination $)$

$\mathrm{O}\left({ }^{1} \mathrm{D}\right)+\mathrm{M} \stackrel{9}{\longrightarrow} \mathrm{O}+\mathrm{M}$

where $\mathrm{RH}$ represents toluene; $\mathrm{M}$ is the background molecule $\left(\mathrm{O}_{2}\right.$ and $\left.\mathrm{N}_{2}\right)$. Using the pseudo-steady state approximation (PSSA) to deal with the free radical intermediates $\left(\mathrm{O}\left({ }^{1} \mathrm{D}\right)\right.$, and $\mathrm{OH}^{\bullet}$ ), we have:

$$
\begin{aligned}
\frac{d C_{\text {toluene }}}{d t}= & r_{\mathrm{UV} / \mathrm{O} 3} \\
= & 2 k_{1} \times \frac{\left[\left(k_{3}+k_{4}\right) / k_{8}\right] C_{\text {toluene }}}{1+\left[\left(k_{3}+k_{4}\right) / k_{8}\right] C_{\text {toluene }}} \\
& \times \frac{\left[k_{2} /\left(k_{9} C_{\mathrm{M}}\right)\right] C_{w}}{1+\left[k_{2} /\left(k_{9} C_{\mathrm{M}}\right)\right] C_{w}} \times C_{\mathrm{O} 3} \\
= & 2 k_{1} \times \frac{k_{2}^{\prime} C_{\text {toluene }}}{1+k_{2}^{\prime} C_{\text {toluene }}} \times \frac{k_{3}^{\prime} C_{w}}{1+k_{3}^{\prime} C_{w}} \times C_{\mathrm{O} 3}
\end{aligned}
$$

where $C_{\text {toluene }}$ is the toluene concentration; $r_{\mathrm{UV} / \mathrm{O} 3}$ is the toluene oxidation rate of $\mathrm{UV} / \mathrm{O}_{3}$ reaction; $k_{1}-k_{4}, k_{8}$, and $k_{9}$ are the rate constants of equations (12.1)-(12.4) and (12.8)-(12.9); $C_{w}$ is the humidity; $C_{\mathrm{M}}$ is the concentration of the background molecule; $\quad k_{3}^{\prime}=k_{2} /\left(k_{9} C_{\mathrm{M}}\right) ; \quad k_{2}^{\prime}=\left(k_{3}+k_{4}\right) / k_{8} ; \quad k_{4}=(0.1 /$ $0.9) \times k_{3}$.

According to Eq. (13), the TOR of $\mathrm{UV} / \mathrm{O}_{3}$ reaction was proportional to ozone concentration, which was consistent with the result in Fig. 7. Rearranging Eq. (13), we have:

$\frac{1}{r_{\mathrm{UV} / \mathrm{O} 3}}=\frac{1}{2 k_{1} C_{\mathrm{O} 3}} \times\left(\frac{1}{k_{2}^{\prime} C_{\text {toluene }}}+1\right) \times\left(\frac{1}{k_{3}^{\prime} C_{w}}+1\right)$

In accordance with Eq. (14), the plots of $1 / r_{\mathrm{UV} / \mathrm{O} 3}$ versus each of $1 / C_{\text {toluene }}$ and $1 / C_{w}$ were linear with positive slopes and intercepts. The fitness of experimental data in Eqs. (13) and (14) is shown in Figs. 7 and 9, respectively, yields the values of $k_{1}=8.14 \times 10^{-4} \mu-\mathrm{mol}-\mathrm{m}^{-3}-\mathrm{s}^{-1} / \mathrm{ppb}^{-\mathrm{O}_{3}}, \quad k_{2}^{\prime}=0.252 \mathrm{ppm}^{-1}$, 


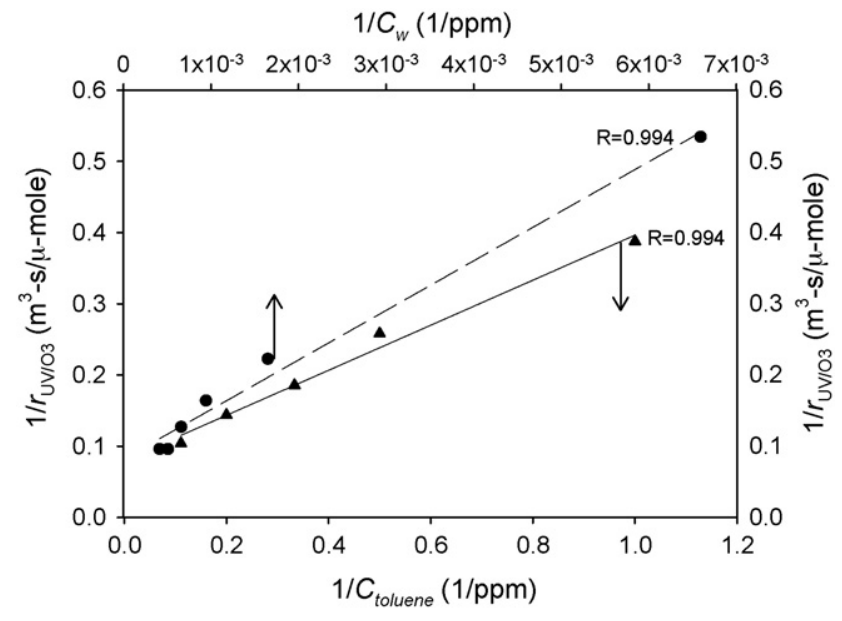

Fig. 9. Relation between $1 / r_{\mathrm{UV} / \mathrm{O} 3}$ and $1 / C_{\text {toluene }}$, and $1 / C_{w^{*}}$

and $k_{3}^{\prime}=1.178 \times 10^{-4} \mathrm{ppm}^{-1}$. Therefore, the rate equation of $\mathrm{UV} / \mathrm{O}_{3}$ reaction can be expressed as the following equation:

$$
\begin{aligned}
r_{\mathrm{UV} / \mathrm{O} 3}= & 1.628 \times 10^{-3} \times \frac{0.252 C_{\text {toluene }}}{1+0.252 C_{\text {toluene }}} \\
& \times \frac{1.178 \times 10^{-4} C_{w}}{1+1.178 \times 10^{-4} C_{w}} \times C_{\mathrm{O} 3}
\end{aligned}
$$

\section{Conclusions}

The TORs of $\mathrm{TiO}_{2} / \mathrm{UV} / \mathrm{O}_{3}, \mathrm{TiO}_{2} / \mathrm{UV}$, and $\mathrm{UV} / \mathrm{O}_{3}$ reactions showed positive correlation with toluene concentration and gas flow rate. Similarly, the $\mathrm{CO}_{2}$ yield rates and IYRs of $\mathrm{TiO}_{2} / \mathrm{UV}$ and $\mathrm{TiO}_{2} / \mathrm{UV} / \mathrm{O}_{3}$ reactions increased with toluene concentration and gas flow rate. However, the toluene conversion decreased when the toluene concentration increased. This designates that the $\mathrm{TiO}_{2} / \mathrm{UV} / \mathrm{O}_{3}, \mathrm{TiO}_{2} / \mathrm{UV}$, and $\mathrm{UV} / \mathrm{O}_{3}$ reactions may be more suitable for treating VOCs contaminations of low concentration than for that of high concentration. The TORs and $\mathrm{CO}_{2}$ yield rates of $\mathrm{TiO}_{2} / \mathrm{UV} / \mathrm{O}_{3}$ reaction were higher than those of $\mathrm{TiO}_{2} / \mathrm{UV}$ reaction. This fact indicates that the $\mathrm{TiO}_{2} / \mathrm{UV} / \mathrm{O}_{3}$ reaction was more efficient than the $\mathrm{TiO}_{2} / \mathrm{UV}$ reaction for removing VOCs pollutants, particularly for treating those of lower concentration, since the IYRs of $\mathrm{TiO}_{2} / \mathrm{UV} / \mathrm{O}_{3}$ reaction was $\leq 0.23 \mu \mathrm{g} / \mathrm{m}^{2}$-s when toluene $\leq 2 \mathrm{ppm}$. The experimental result showed that the kinetics of $\mathrm{TiO}_{2} / \mathrm{UV} / \mathrm{O}_{3}$ and $\mathrm{TiO}_{2} / \mathrm{UV}$ reactions fits the $\mathrm{L}-\mathrm{H}$ rate form.

Because water molecule was involved in the formation of hydroxyl radical and the competitive adsorption, humidity has a dual effect on the TOR and $\mathrm{CO}_{2}$ yield rate of $\mathrm{TiO}_{2} / \mathrm{UV}$ reaction. Increase of humidity had a negative effect on the ORE of $\mathrm{TiO}_{2} /$ $\mathrm{UV} / \mathrm{O}_{3}$ reaction. The TORs of $\mathrm{TiO}_{2} / \mathrm{UV} / \mathrm{O}_{3}$ and $\mathrm{UV} / \mathrm{O}_{3}$ reactions were proportional to ozone concentrations, and the enhancement index of $\mathrm{O}_{3}$ of $\mathrm{TiO}_{2} / \mathrm{UV} / \mathrm{O}_{3}$ and $\mathrm{UV} / \mathrm{O}_{3}$ reactions were $7.49 \times 10^{-6}$ and $5.71 \times 10^{-6} \mu-\mathrm{mol}-\mathrm{m}^{-2}-\mathrm{s}^{-1} / \mathrm{ppb}-\mathrm{O}_{3}$, respectively. The ORE of $\mathrm{TiO}_{2} / \mathrm{UV} / \mathrm{O}_{3}$ reaction ranged from 38.1 to $99.5 \%$, and showed positive correlations with toluene concentration and retention time, and showed negative correlations with humidity and $\mathrm{O}_{3}$ concentration. The kinetic of ozone removals of $\mathrm{TiO}_{2} / \mathrm{UV} / \mathrm{O}_{3}$ reaction fits the $\mathrm{L}-\mathrm{H}$ rate form. The ORE of $\mathrm{UV} / \mathrm{O}_{3}$ reaction increased with retention time and humidity. The ozone removals of $\mathrm{UV} / \mathrm{O}_{3}$ reaction were first order regarding ozone concentration.

\section{Acknowledgement}

The authors would like to thank National Science Council of Republic of China for funding the research project of contract number 93-EPA-Z-002-007.

\section{References}

[1] H.J. Seinfeld, S.N. Pandis, Atmospheric Chemistry and Physics, John Wiley \& Sons Inc., New York, 1998.

[2] Y.M. Kim, S. Harrad, R.M. Harrison, Environ. Sci. Technol. 35 (2001) 97.

[3] J.L. Repace, Environ. Int. 8 (1982) 21.

[4] J. Peral, X. Domènech, D.F. Ollis, J. Chem. Technol. Biotechnol. 70 (1997) 117.

[5] L.M. Sattler, H.M. Liljestrand, J. Air Waste Manage. Assoc. 53 (2003) 3.

[6] J. Zhao, X. Yang, Build. Environ. 30 (2003) 645.

[7] A.J. Maira, K.L. Yeung, J. Soria, J.M. Coeonado, C. Belver, C.Y. Lee, V. Augugliaro, Appl. Catal. B: Environ. 29 (2001) 327.

[8] M. Lewandowski, D.F. Ollis, Appl. Catal. B: Environ. 43 (2003) 309.

[9] E. Piera, J.A. Ayllón, X. Doménech, J. Peral, Catal. Today 76 (2002) 259.

[10] L. Cao, Z. Gao, S.L. Suib, T.N. Obee, S.O. Hay, J.D. Freihaut, J. Catal. 196 (2000) 253.

[11] M.L. Sauer, D.F. Ollis, J. Catal. 163 (1996) 215.

[12] M.C. Blount, J.L. Falconer, Appl. Catal. B: Environ. 39 (2002) 39.

[13] R. Ménddez-Román, N. Cardona-Matínez, Catal. Today 40 (1998) 353.

[14] S.B. Kim, C.H. Sung, Appl. Catal. B: Environ. 35 (2002) 305.

[15] R.M. Alberici, W.F. Jardim, Appl. Catal. B: Environ. 14 (1997) 58.

[16] W. Wang, L.-W. Chiang, Y. Ku, J. Hazard. Mater. B 101 (2003) 133.

[17] J. Jeong, K. Sekiguchi, K. Sakamoto, Chemosphere 57 (2004) 663.

[18] Agency for Toxic Substances and Disease Registry (ATSDR), Toxicological Profile for Toluene (Update), U.S. Public Health Service, U.S. Department of Health and Human Services, Atlanta, GA, 1994.

[19] A.P. Jones, Atmos. Environ. 33 (1999) 4535.

[20] D.W. VanOsdell, ASHRAE Trans. 100 (1994) 511.

[21] I. Andersen, G.R. Lundqvist, L. Molhave, Scand. J. Work Environ. Health 9 (1983) 405.

[22] J. Baelum, I. Andersen, G.R. Lundqvist, Scand. J. Work Environ. Health 11 (1985) 271.

[23] D. Echeverria, L. Fine, G. Langolf, A. Schork, C. Sampaio, Br. J. Ind. Med. 46 (1989) 483.

[24] H. Einaga, S. Futamura, T. Ibusuki, Appl. Catal. B: Environ. 38 (2002) 215.

[25] R.H. Perry, D.W. Green, J.O. Maloney, Perry's Chemical Engineers' Handbook, seventh ed., McGraw-Hill, New York, 1997.

[26] Y. Luo, D.F. Ollis, J. Catal. 163 (1996) 1.

[27] T. Obee, R.T. Brown, Environ. Sci. Technol. 29 (1995) 1223.

[28] P. Pichat, J. Disdier, C. Hoang-Van, D. Mas, G. Goutailler, C. Gaysse, Catal. Today 63 (2000) 363.

[29] H. Al-Ekabi, B. Butters, D. Delany, W. Holden, T. Powell, J. Story, in: D.F. Ollis, H. Al-Ekabi (Eds.), Photocatalytic Purification and Treatment of Water and Air, Elsevier Science Publishers B.V., Amsterdam, 1993, pp. 719-725.

[30] A.W. Adamson, Physical Chemistry of Surfaces, fourth ed., John Wiley \& Sons, New York, 1982.

[31] V. Augugliaro, S. Coluccia, V. Loddo, L. Marchese, G. Martra, L. Palmisano, M. Schiavello, Appl. Catal. B: Environ. 20 (1999) 15.

[32] M. Bhowmick, M.J. Semmens, Wat. Res. 28 (1994) 2407. 